\title{
Effects of elevated temperature on the performance and survival of pacific crown-of-thorns starfish (Acanthaster cf. solaris)
}

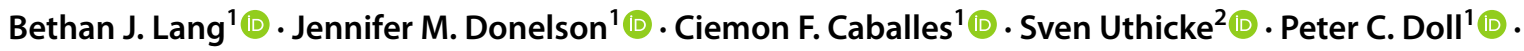 \\ Morgan S. Pratchett ${ }^{1} \mathbb{D}$
}

Received: 31 August 2021 / Accepted: 31 January 2022 / Published online: 3 March 2022

(c) The Author(s) 2022

\begin{abstract}
Population irruptions of Pacific crown-of-thorns starfish (Acanthaster cf. solaris) have caused substantial damage to coral reefs, but it is largely unknown how this asteroid will fare in a warmer ocean. We exposed these starfish to one of four thermal treatments, with final temperatures of $26^{\circ} \mathrm{C}$ (control, annual average), $28^{\circ} \mathrm{C}$ (summer average), $30{ }^{\circ} \mathrm{C}$ (summer maximum) and $32{ }^{\circ} \mathrm{C}$ (predicted summer maximum by 2100 ). We measured the righting time, movement rate, standard metabolic rate and probability of survival of the crown-of-thorns starfish at various timepoints over $\sim 60$ days. We found that while temperature did not affect righting time, it did significantly affect movement rate. The movement rate of starfish increased across the 26 to $30{ }^{\circ} \mathrm{C}$ range, with those at $28^{\circ} \mathrm{C}$ and $30{ }^{\circ} \mathrm{C}$ moving 18 and $27 \%$ faster than those at the control temperature. Similarly, the standard metabolic rate of starfish increased from 26 to $30{ }^{\circ} \mathrm{C}$, with metabolism $100 \%$ and $260 \%$ faster at $28^{\circ} \mathrm{C}$ and $30^{\circ} \mathrm{C}$ compared to those at the $26^{\circ} \mathrm{C}$ control. At $32{ }^{\circ} \mathrm{C}$, individual starfish exhibited a $14 \%$ slower movement rate, a $33 \%$ slower metabolic rate, and also exhibited a fourfold lower probability of survival than those at $30{ }^{\circ} \mathrm{C}$. These results indicate that $32{ }^{\circ} \mathrm{C}$ is above the thermal optimum of crown-of-thorns starfish, suggesting that prolonged exposure to temperatures that are expected to be regularly exceeded under near-future climate change may be detrimental to this species.
\end{abstract}

Keywords Climate change $\cdot$ Coral reefs $\cdot$ Behaviour $\cdot$ Movement $\cdot$ Metabolic rate $\cdot$ Mortality

\section{Introduction}

Population irruptions of the coral-feeding Pacific crown-ofthorns starfish (Acanthaster $\mathrm{cf}$. solaris; CoTS) and climate change are considered two of the greatest contributors to coral loss, especially in the western Pacific (De'ath et al. 2012; Baird et al. 2013; van Hooidonk et al. 2016; Mellin et al. 2019; Castro-Sanguino et al. 2021). The tropical and subtropical waters surrounding coral reefs have warmed approximately $\sim 1{ }^{\circ} \mathrm{C}$ since pre-industrial times (Lough et al. 2018; Negri et al. 2020), and climate change projections

Responsible Editor: A.E. Todgham.

Bethan J. Lang

bethan.lang@my.jcu.edu.au

1 Australian Research Council Centre of Excellence for Coral Reef Studies, James Cook University, Townsville, QLD 4811, Australia

2 Australian Institute of Marine Science, PMB No. 3, Townsville, QLD 4810, Australia indicate that they will likely heat further over the coming decades (IPCC 2013, 2021). Climate change is already having significant impacts on coral reef ecosystems in the form of a higher incidence and severity of marine heatwaves in recent years (GBRMPA 2019; Bureau of Meteorology 2020; IPCC 2021). These short-term periods of abnormally high ocean temperatures (by definition, when the temperature exceeds the 90th percentile for at least five consecutive days; Hobday et al. 2016), have resulted in mass coral bleaching events (van Hooidonk et al. 2016; Bureau of Meteorology 2020). Extreme temperatures and CoTS predation are considered to have cumulative or synergistic negative effects on corals, reducing the resilience of coral reef ecosystems (Vercelloni et al. 2017; Kamya et al. 2018; Haywood et al. 2019; Keesing et al. 2019; Castro-Sanguino et al. 2021). However, in order to predict the future resilience of the reef, the direct impact of ocean warming on this coral predator must be considered (Lang et al. 2021).

For ectothermic species, such as asteroids, environmental temperature is a strong determinant of the rate of physiological processes, which affects the ability of these individuals 
to move in their natural environment (Kidawa et al. 2010; Nguyen et al. 2011; Brothers and McClintock 2015; Illing et al. 2020). Measuring the time it takes for an individual to return to its natural orientation following inversion (righting time) is a useful measure of neuromuscular coordination (Kleitman 1941; Reese 1966; Binyon 1972) and has been used as a proxy for overall performance in response to temperature in echinoderms (Peck et al. 2008; Kidawa et al. 2010; Wood et al. 2010; Brothers and McClintock 2015). In the starfish Odontaster validus, while temperatures of $2{ }^{\circ} \mathrm{C}$ above ambient had little effect on righting time, starfish righted more slowly when heated by a further degree (Kidawa et al. 2010). Likewise, the sea urchin Heliocidaris erythrogramma righted at similar speeds at ambient temperature and with a $2{ }^{\circ} \mathrm{C}$ temperature increase, but a further degree of warming more than doubled the righting time (Minuti et al. 2021). In contrast, several studies have found that the righting time of echinoderms, such as the sea urchin Strongylocentrotus intermedius (Zhang et al. 2017) and the brittle star Ophiura ophiura (Wood et al. 2010), changed very little with $3{ }^{\circ} \mathrm{C}$ and $4.5^{\circ} \mathrm{C}$ of warming (above ambient), respectively. Rates of movement along a surface serves as another useful proxy for performance in a warmer environment, but is rarely studied in echinoderms (but see Kidawa et al. 2010). This behaviour may be even more thermosensitive than righting, with the movement rate of $O$. validus increasing only until $1{ }^{\circ} \mathrm{C}$ above ambient temperature, but declining with an additional degree of warming (Kidawa et al. 2010). Activity rate declines in marine organisms at high temperatures may diminish the ability to effectively escape predators and seek out suitable prey, lessening the capacity to meet the heightened energetic demands in a warmer ocean (Pörtner and Knust 2007; Peck et al. 2008; Kidawa et al. 2010; Wood et al. 2010; Brothers and McClintock 2015; Sun et al. 2018).

It is a general physiological rule that the standard metabolic rate (SMR) increases with temperature, in an attempt to meet the greater energy requirement for maintenance of homeostasis (Peck and Prothero-Thomas 2002; Clarke and Fraser 2004). However, there are limits to the capacity to supply sufficient oxygen to sustain metabolism, produce enough energy to support normal cellular processes, and maintain organism performance and fitness (Lawrence 1984; Pörtner 2001, 2002; Pörtner et al. 2017). Harianto et al. (2018), for instance, observed significant declines in SMR and survival at $26{ }^{\circ} \mathrm{C}\left(\sim 4{ }^{\circ} \mathrm{C}\right.$ above the average summer temperature, AST) in the temperate sea urchin $H$. erythrogramma. Observed metabolic depression at elevated temperatures is largely a consequence of the increased reliance on anaerobic metabolism, which is much less efficient at producing energy than aerobic metabolism (Pörtner 2001, 2002; Pörtner et al. 2017; Lang et al. 2021). Evidence for this has been observed in CoTS at the biochemical level, with reduced activity of citrate synthase (a proxy for aerobic capacity) and increased activity of lactate dehydrogenase (a proxy for anaerobic capacity) at warmer temperatures (Lang et al. 2021). The consequent hypoxia contributes towards the disruption of cellular oxidative phosphorylation, protein denaturation, mitochondrial failure and ultimately mortality, which often occur after extended exposure to elevated temperatures (Chen and Chen 1993; Pörtner 2001, 2002; Peck et al. 2009; Fang et al. 2015a, b; Christensen et al. 2011, 2017; Pörtner et al. 2017; Harianto et al. 2018).

In many marine ectotherms, including CoTS, thermal sensitivity is not uniform across life stages, and sensitivity to elevated temperature often varies depending on the measures assessed (e.g., Rupp 1973; Kashenko 2006; Rahman et al. 2009; Byrne et al. 2013; Uthicke et al. 2015; Caballes et al. 2017). Laboratory-based investigations have demonstrated that gametogenesis and the early life stages of CoTS are thermosensitive, whereby 2 to $4{ }^{\circ} \mathrm{C}$ warming (above AST) results in smaller eggs and a lower gonado-somatic index (Hue et al. 2020), as well as reduced fertilisation success (Caballes et al. 2017; Hue et al. 2020), and proportion of embryos and larvae undergoing normal development (Kamya et al. 2014; Caballes et al. 2017; Sparks et al. 2017). In contrast, the same degree of warming either enhances or does not affect the development rate (Lamare et al. 2014; Uthicke et al. 2015), survival (Lamare et al. 2014; Uthicke et al. 2015) and growth (Lamare et al. 2014) of larvae, as well as the growth of algae-feeding (Kamya et al. 2016) and coral-feeding juveniles ( $<1.5 \mathrm{~cm}$; Kamya et al. 2018). Larger coral-feeding CoTS may be more thermally robust, as shown in a recent study where the metabolic rate of subadults was found to increase with temperature to at least $36{ }^{\circ} \mathrm{C}$, and metabolic depression was only observed in adult CoTS from $33{ }^{\circ} \mathrm{C}\left(>5{ }^{\circ} \mathrm{C}\right.$ above AST; Lang et al. 2021). However, these individuals were exposed to acute ramping trials (rate of increase, $1{ }^{\circ} \mathrm{C} \mathrm{h}^{-1}$; Lang et al. 2021) and thus may not experience additional physiological costs that are associated with the longer durations of heat exposure that naturally occur on the reef (Pörtner 2001, 2002; Pörtner et al. 2017). Whether coral-feeding juvenile $(>1.5 \mathrm{~cm})$, subadult and adult CoTS experience compromised performance at cooler temperatures with prolonged exposure, remains to be tested.

Understanding how the coral-feeding life stages of CoTS perform in a warmer environment is essential for predicting the future impact of this predator on the reef. Herein, we explored the effect of prolonged ( $\sim 60$ days) exposure to various thermal treatments in Pacific CoTS from Australia's Great Barrier Reef (GBR). The size range tested incorporates large coral-feeding $(>5.5 \mathrm{~cm})$ juveniles, as well as sub-adults and adults (Pratchett et al. 2014; 2021; Caballes 2017). The measures used to assess the effect of temperature on this species were: righting 
time, average movement rate, SMR (weight-specific) and probability of survival. Because it is considered that species that inhabit coral reefs are living particularly close to their thermal limits (Stuart-Smith et al. 2015; Negri et al. 2020), we hypothesised that temperatures of only a few degrees above the AST will compromise performance during prolonged exposure to elevated temperatures (Lang et al. 2021). Compromised performance and increased mortality of CoTS in a warmer ocean will unequivocally lead to population contractions (Eisenlord et al. 2016), and possibly re-distributions (Ling 2013; Sill and Dawson 2021), with variable impacts on the corals that they interact with.

\section{Materials and methods}

\section{Collection and maintenance}

We collected Pacific crown-of-thorns starfish $(n=48$, 10-1556 g, 5.5-38 cm diameter), from mid-shelf reefs in the central GBR between 28 and 30th January 2020, at depths of 2-8 $\mathrm{m}$. These reefs were Big Broadhurst $\left(18^{\circ} 58^{\prime} \mathrm{S}, 147^{\circ} 43^{\prime} \mathrm{E}\right)$, Keeper $\left(18^{\circ} 45^{\prime} \mathrm{S}, 147^{\circ} 17^{\prime} \mathrm{E}\right)$, Kelso $\left(18^{\circ} 26^{\prime} \mathrm{S}, 146^{\circ} 59^{\prime} \mathrm{E}\right)$, Little Broadhurst $\left(18^{\circ} 56^{\prime} \mathrm{S}\right.$, $\left.147^{\circ} 41^{\prime} \mathrm{E}\right)$, Little Kelso $\left(18^{\circ} 28^{\prime} \mathrm{S}, 146^{\circ} 59^{\prime} \mathrm{E}\right)$, Lodestone $\left(18^{\circ} 42^{\prime} \mathrm{S}, 147^{\circ} 06^{\prime} \mathrm{E}\right)$, and Rib $\left(18^{\circ} 28^{\prime} \mathrm{S}, 146^{\circ} 53^{\prime} \mathrm{E}\right)$. Sea surface temperatures at the collection locations generally range from $24{ }^{\circ} \mathrm{C}$ to $29{ }^{\circ} \mathrm{C}$ annually (AIMS 2021a), and at the time of collection the temperature of the water was $28-29^{\circ} \mathrm{C}$. These CoTS were transported to the Marine and Aquaculture Research Facilities Unit (MARFU), James Cook University, Townsville, in flow-through aquaria. Upon arrival, we placed the starfish individually in $42 \mathrm{~L}$ tanks attached to one of four semi-closed recirculating systems (which would eventually become the four temperature treatments). The water temperature was set to $26^{\circ} \mathrm{C}$, which is the annual average temperature in the collection vicinity (AIMS 2021a). The seawater was naturally at $\mathrm{pH} 8.24$ and had a salinity of $37.5 \mathrm{ppt}$. The systems were housed within a temperature-controlled room with a $12 \mathrm{~h}: 12 \mathrm{~h}$ light:dark cycle. We acclimated the CoTS to laboratory conditions in these tanks for 25 days. We did not feed the CoTS throughout the acclimation period and the duration of experiments, to avoid any potential effect of differential feeding on individual performance (sensu Caballes et al. 2016). This starvation unlikely impacted energy reserves to a significant extent, due to the low levels of activity of CoTS in the laboratory, and the fact that they are known to survive for many months without feeding (Moran 1988).

\section{Experimental design}

We commenced the experiments to assess righting time and average movement rate after the acclimation period on 24th February 2020. Starfish were distributed evenly among four treatments $\left(26,28,30\right.$ and $32{ }^{\circ} \mathrm{C}, n=12$ per treatment). The treatment names represent the final temperatures experienced by the starfish rather than the temperatures at the beginning of the experiments $\left(26{ }^{\circ} \mathrm{C}\right.$ in all treatments, Fig. 1). The mean weights of these starfish were $313,193,309$ and $294 \mathrm{~g}$ for the $26,28,30$ and $32{ }^{\circ} \mathrm{C}$ treatment, respectively. The weights of the starfish were not significantly different among treatment groups (LM, $F=0.30$, $d f=3, p=0.819$ ). We initially tested the starfish in each of the temperature treatments at the control temperature of $26{ }^{\circ} \mathrm{C}$ (day 1), after which we raised the temperatures in the 28,30 and $32{ }^{\circ} \mathrm{C}$ treatments to $28^{\circ} \mathrm{C}$, before repeating the experiments on all 48 starfish (week 2, day 8). Upon completion, we further raised the temperatures of the $30^{\circ} \mathrm{C}$ and $32{ }^{\circ} \mathrm{C}$ treatment systems to $30{ }^{\circ} \mathrm{C}$, and again repeated the experiments (week 3, day 15). Finally, we raised the temperatures of the $32{ }^{\circ} \mathrm{C}$ treatment to $32{ }^{\circ} \mathrm{C}$, and we completed the last round of righting and movement experiments, with all starfish being at their final temperatures (week 4, day 22, Fig. 1). In between each week, we raised the temperatures in the relevant treatments at rates of $0.5{ }^{\circ} \mathrm{C}$ day $^{-1}$, which allowed for a three-day acclimation period at the testing temperature before experiments commenced. The treatments were warmed gradually rather than immediately exposing starfish to their final temperatures, in order for the environmental conditions to be more representative of those that may be experienced by CoTS in nature, during a warming event (AIMS 2021a, b). The temperature of the seawater in the systems was on average $\pm 0.25{ }^{\circ} \mathrm{C}$ around the set-point level throughout the experiments.

We tested the SMR of each starfish twice unless mortality occurred before testing. One run (same week, SW) involved testing the SMR of all surviving starfish between days 32-35 for the $26(n=12), 28(n=12), 30(n=11)$ and $32{ }^{\circ} \mathrm{C}(n=8)$ temperature treatments (Fig. 1). The CoTS were tested over the same four days in order to control for an effect of time in the laboratory. To further control for an effect of time, we tested starfish from all four treatments each day. The other run (consecutive weeks, $\mathrm{CW}$ ) involved testing the SMR of the same starfish exactly 4 weeks after first exposure to the final temperatures for each treatment (except in the case of the $26{ }^{\circ} \mathrm{C}$ control). Specifically, testing occurred on days 29-30 for the $26^{\circ} \mathrm{C}$ treatment $(n=12)$, day 36 for the $28^{\circ} \mathrm{C}$ treatment $(n=11)$, day 43 for the $30{ }^{\circ} \mathrm{C}$ treatment $(n=11)$ and day 50 for the $32{ }^{\circ} \mathrm{C}$ treatment $(n=3)$ (Fig. 1). On each of the warmer testing days (days 36,43 and 50), we re-tested the same six starfish from the $26{ }^{\circ} \mathrm{C}$ control treatment in order to control for any effect of time, however there was no 


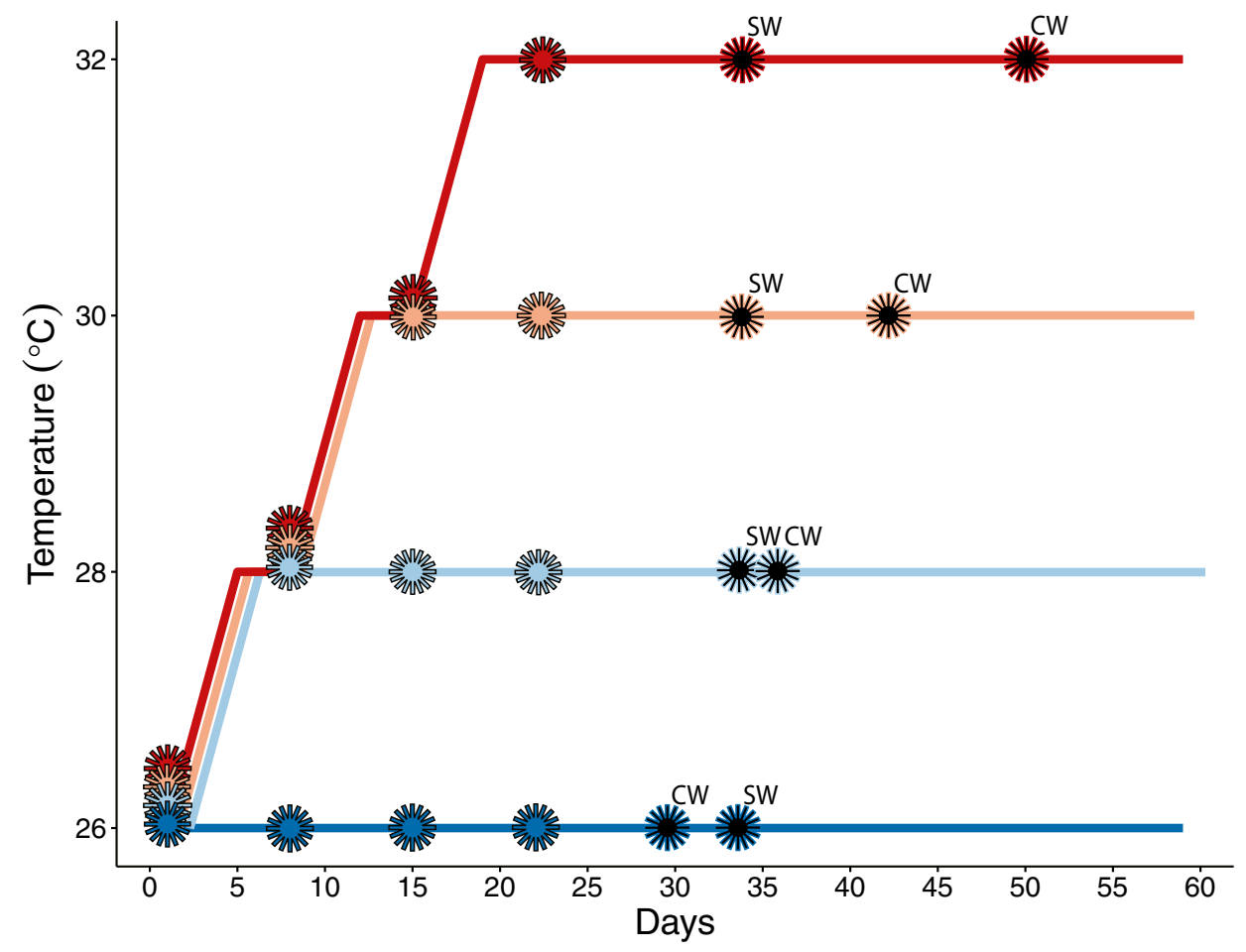

Fig. 1 Experimental design timeline. The figure indicates the temperature profiles for the $26{ }^{\circ} \mathrm{C}$ (dark blue), $28{ }^{\circ} \mathrm{C}$ (light blue), $30{ }^{\circ} \mathrm{C}$ (orange) and $32{ }^{\circ} \mathrm{C}$ (red) treatments, from day 1 of the study until day 59. Experiments to assess righting time and average movement rate (symbols with coloured fill) were carried out on days 1, 8, 15 and 22 for all Acanthaster $\mathrm{cf}$. solaris during the temperature ramping period. Experiments to measure the standard metabolic rate of the starfish (symbols with black fill) took place after endpoint temperatures were

significant effect of this variable $(p=0.529)$. We conducted the $\mathrm{CW}$ run in order to account for an effect of differing lengths of time at the final temperatures among temperature treatments, and to allow for better assessment of the exposure-time dependence of thermal effects on physiological performance.

We checked the CoTS once or twice per day for mortality from day 1 until day 59 (Fig. 1). Starfish were considered deceased when they exhibited all or a number of typical indicators of mortality, such as flattened or detached spines, lesion formation, exposure of internal organs and loss of turgor. Upon death, we immediately removed the starfish in order to avoid system contamination, and they were not replaced. We recorded the time of death for later analysis.

\section{Righting time and movement rate}

We conducted the experiments to measure the righting time and average movement rate for each CoTS in one of four $1.1 \mathrm{~m}$ diameter round aquaria, connected to their respective recirculation systems to ensure consistency of environmental conditions. To measure righting time (s), reached. The same week ' $\mathrm{SW}$ ' run was carried on days 32 to 35 on all starfish, while the consecutive weeks ' $\mathrm{CW}$ ' run was conducted on days $29-30,36,43$ and 50 for the $26,28,30$ and $32{ }^{\circ} \mathrm{C}$ treatments, respectively. The overlapping lines of the four treatments were offset horizontally, so that their complete temperature profiles could be visualised. The overlapping symbols were offset vertically. Experiments began with $n=12$ starfish per treatment, and any mortality was recorded over the 59 days

we inverted the starfish and placed them in the centre of the aquarium, and permitted them to return to their natural orientation. Once righted, we allowed the starfish to move from the centre to the edge of the aquarium. We video recorded all responses using GoPro Hero 7 cameras (GoPro Inc., California, USA) for later analysis. We determined the righting time and mode of righting (the style of movement used to return to the correct orientation) from the videos. Three modes of righting were utilised by the CoTS. Mode 1 involved the starfish raising all arms upwards so that they were almost touching, causing them to tip to side. The top arms finally moved over the bottom arms until they reached the surface. Starfish utilising mode 2 raised some arms upwards so that they were almost touching, while the other arms bent backwards in order for them to flip themselves over. Mode 3 involved the starfish bending their arms backwards and flipping themselves over without raising their arms up first. We used Adobe After Effects software (Adobe Systems Inc., California, USA) to establish the average rates of movement $\left(\mathrm{cm} \mathrm{min}^{-1}\right)$ over the total distance travelled (the sum of the distance travelled in all directions). 


\section{Standard metabolic rate}

To assess the SMR of the starfish in the four temperature treatments, we used intermittent-flow respirometry (Clark et al. 2013; Svendsen et al. 2016; Kühnhold et al. 2019; Lang et al. 2021). We placed four acrylic respirometry chambers of various sizes $(4.12,9.99$ and $21.77 \mathrm{~L})$ within a $1000 \mathrm{~L}$ capacity water bath. Flush pumps (flow rate; 400 to 500 $\mathrm{L} \mathrm{h}^{-1}$ ) delivered oxygenated water from the water bath into the chambers between measurement periods, and snorkels attached to the top of the chambers expelled oxygen depleted water. Recirculatory pumps (flow rate; 400 to $500 \mathrm{~L} \mathrm{~h}^{-1}$ ) enabled the water within the chambers to constantly mix. We glued oxygen sensor spots to the recirculatory tubing with silicone gel, and aligned them with Firesting oxygen probes (PyroScience, Aachen, Germany). These probes delivered oxygen depletion data via a Pyro oxygen meter into the PyroScience program installed on a computer via fibre-optic cables. A chiller and two heaters $(1 \mathrm{~kW})$ cooled/ heated the water to the final temperature for the 26, 28, 30 and $32{ }^{\circ} \mathrm{C}$ treatments prior to the introduction of the starfish. We ran four chambers at once (three containing starfish, with one left empty to control for background respiration). We allowed the starfish to settle in the chambers for $45 \mathrm{~min}$ with the flush pumps switched on, after which we sealed the chambers, and measured oxygen depletion in each chamber over $30 \mathrm{~min}$. After the measurement period we again switched on the flush pumps, enabling oxygen levels in the chambers to return to $100 \%$. We tested four to six cohorts of starfish each day between 09:00 and 20:30.

For consistency we removed the first eight minutes from all oxygen depletion slopes, as a consequence of a delay in the water within the sealed chambers becoming completely mixed. We subtracted the slopes for background respiration from each run from the CoTS respiration slopes. We calculated the weight-specific SMR in $\mathrm{mg} \mathrm{O}_{2} \mathrm{~g}^{-1} \mathrm{~h}^{-1}$ following Svendsen et al. (2016).

\section{Statistical analysis}

We carried out all statistical analyses in R Studio (version 1.1.463, RStudioTeam 2016). We analysed the effect of temperature (at the time of testing) on righting time (s) using a linear mixed effects model. We log-transformed the response in order to meet the normality assumption. We also included the experimental week, the log-transformed starfish wet weight $(\mathrm{g})$ and mode of righting as covariates, to control for differences in these variables among temperature treatments. We included Starfish ID as a random effect to account for the repeated measures design. In addition, we conducted a Fisher's exact test in order to establish whether there was an association between temperature and the mode of righting utilised by the starfish.
We used an additional linear mixed effects model to establish the effect of temperature on the average movement rate $\left(\mathrm{cm} \mathrm{min}^{-1}\right)$. Again, we included the experimental week, the log-transformed wet weight (g) and starfish ID in the model, in addition to the log-transformed distance travelled $(\mathrm{cm})$. We excluded observations from the analysis if the starfish did not move within 20 min of righting $(n=3)$. As a result of the significance of wet weight in influencing the average movement rate, we explored this relationship further by establishing the scaling exponent $(b)$, which is the slope value of this factor and the response. This value was calculated for each temperature using linear ordinary least squares regression analyses. We extracted the estimated marginal means for the righting time (on the response scale) and average movement rate of the starfish for all temperatures. These are the means that have been adjusted for covariates in the model i.e., weight, mode of righting and distance travelled. These estimated marginal means were used for further data investigation including post-hoc comparisons using the Tukey method.

We analysed the SMR (log-transformed, $\mathrm{mg} \mathrm{O}_{2} \mathrm{~g}^{-1}$ $\mathrm{h}^{-1}$ ) using a further linear mixed effects model. We included temperature treatment and run as interacting fixed effects, and starfish ID as a random effect. We removed observations from the analysis that were so low that they could not be distinguished from background respiration $(n=3)$. We used the estimated marginal means (on the response scale) of SMR in the four treatments for post-hoc analysis, including comparisons using the Tukey method. As a result of there being little effect of the run in the model, we only report the compiled estimated marginal means for the four treatments. However, these estimated marginal means adjust for other factors in the model. We calculated the temperature $\left(\mathrm{Q}_{10}\right)$ coefficient between the estimated marginal means of the four treatments in order to establish thermal sensitivity, using the equation by Prosser (1991). For each treatment we also established the scaling exponents $(b)$ for the relationship between the natural logarithms of SMR at the organism level $\left(\mathrm{mg} \mathrm{O}_{2} \mathrm{~h}^{-1}\right)$ and weight $(\mathrm{g})$. These was calculated using linear ordinary least squares regression analyses.

We explored the survival probability (\%) for the starfish in the four temperature treatments using a Kaplan-Meier survival plot and an accompanying log-rank test. Pairwise comparisons were conducted using the Benjamini-Hochberg method. We also conducted a Cox proportional hazards model in order to determine the hazard ratios associated with the three elevated treatments. These models are unable to include groups with no 'events', and therefore we eliminated the $26^{\circ} \mathrm{C}$ control treatment (no mortality, see results) from this analysis. We also conducted a Cox proportional hazards model to observe the hazard ratios for the effect of wet weight $(\mathrm{g})$ on the probability of survival. 


\section{Results}

\section{Righting time and movement rate}

We found no significant impact of temperature on righting time (Fig. 2a, Table 1, see S1 in Online Resource), and no significant effect of the experimental week or the wet weight of the starfish (Table 1). Likewise, we did not find that temperature significantly influenced the mode of righting utilised (Fisher's exact test, $p=0.328$ ), although we did find that there was a significant effect of mode of righting on righting time (Table 1). Starfish utilising mode 3 righted the fastest, with an average righting time of $158 \pm 35 \mathrm{~s}$. This was also the rarest mode of righting $(n=4)$. Mode 1 was the second fastest mode of righting $(194 \pm 13 \mathrm{~s})$, and was the most commonly used by the CoTS $(n=161)$. Starfish utilising mode 2 of righting were the slowest ( $n=26,258 \pm 27 \mathrm{~s})$.

We found a significant effect of temperature on the average movement rate of the starfish (Table 1). There was an 18 and $27 \%$ faster movement rate of starfish at $28^{\circ} \mathrm{C}$ and $30{ }^{\circ} \mathrm{C}$, respectively, compared to those at $26^{\circ} \mathrm{C}$. However, starfish at $32{ }^{\circ} \mathrm{C}$ were $14 \%$ slower than those at $30{ }^{\circ} \mathrm{C}$ (Fig. 2b, see S1 in Online Resource). Rates of movement did not vary significantly among experimental weeks, although we did find a significant effect of distance travelled and wet weight on average movement rate. Starfish that had faster rates of movement travelled further to reach the edge of the aquaria and were heavier (Table 1). The positive relationship between wet weight and movement

a

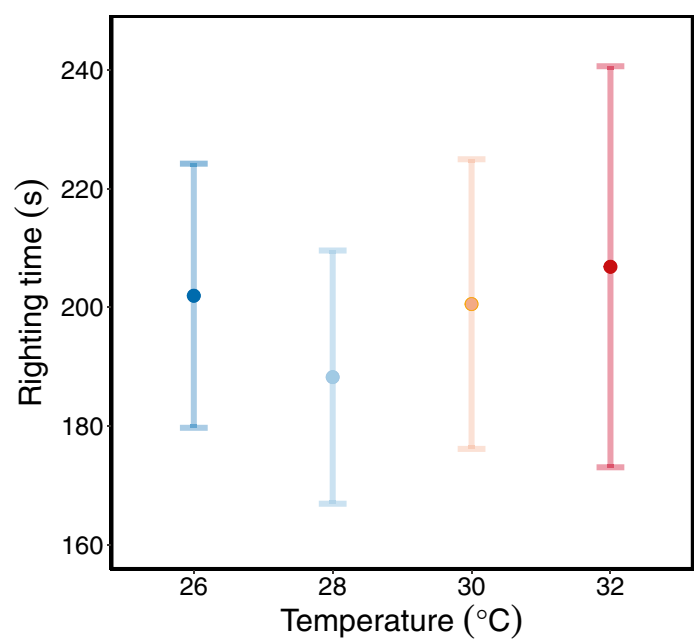

Fig. 2 The effect of temperature on a righting time (s) and $\mathbf{b}$ average movement rate $\left(\mathrm{cm} \mathrm{min}^{-1}\right)$ in Acanthaster $\mathrm{cf}$. solaris $(n=48$ CoTS, $n=191$ righting time observations, $n=188$ average movement rate
Table 1 Output of the linear mixed effects models on the effect of temperature on righting time (s) and average (Av) movement rate $\left(\mathrm{cm} \mathrm{min}{ }^{-1}\right.$ ) in Acanthaster $\mathrm{cf}$. solaris $(n=48$ CoTS, $n=191$ righting time observations, $n=188$ average movement rate observations).

\begin{tabular}{llllr}
\hline Response & Factor & Num $d f$, Den $d f$ & F & $p$ value \\
\hline Righting time & Temperature & 3,179 & 0.24 & 0.871 \\
$(\mathrm{~s})^{*}$ & $\begin{array}{l}\text { Experimental } \\
\text { week }\end{array}$ & 3,164 & 1.20 & 0.312 \\
& Wet weight* & 1,47 & 0.17 & 0.686 \\
& Mode of right- & 2,181 & 5.94 & $\mathbf{0 . 0 0 3}$ \\
& ing & & & \\
Av. Move- & Temperature & 3,173 & 3.42 & $\mathbf{0 . 0 1 9}$ \\
ment rate $_{\left(\text {cm min }^{-1}\right)}$ & Experimental & 3,162 & 1.26 & 0.290 \\
& week & & & \\
& Wet weight* & 1,55 & 73.88 & $<\mathbf{0 . 0 0 1}$ \\
& Distance trav- & 1,184 & 9.24 & $\mathbf{0 . 0 0 3}$ \\
& elled* & & & \\
\hline
\end{tabular}

The influence of the covariates: experimental week, wet weight $(\mathrm{g})$ mode of righting and distance travelled $(\mathrm{cm})$ are also included. Responses and covariates with an asterisk (*) were log-transformed in the models to meet the normality assumption. Significant $p$ values are in bold

rate was similar between 26 and $30^{\circ} \mathrm{C}(b=3.58-3.93)$, but was lower at $32{ }^{\circ} \mathrm{C}(b=1.80$, see $\mathrm{S} 2$ in Online Resource $)$.

\section{Standard metabolic rate}

We found that temperature treatment significantly influenced the SMR (Table 2). The SMR was $100 \%\left(\mathrm{Q}_{10}: 32.0\right)$ and $260 \%\left(\mathrm{Q}_{10}: 24.6\right)$ higher in the $28{ }^{\circ} \mathrm{C}$ and $30{ }^{\circ} \mathrm{C}$ treatments compared to the $26{ }^{\circ} \mathrm{C}$ treatment, respectively. However,

b

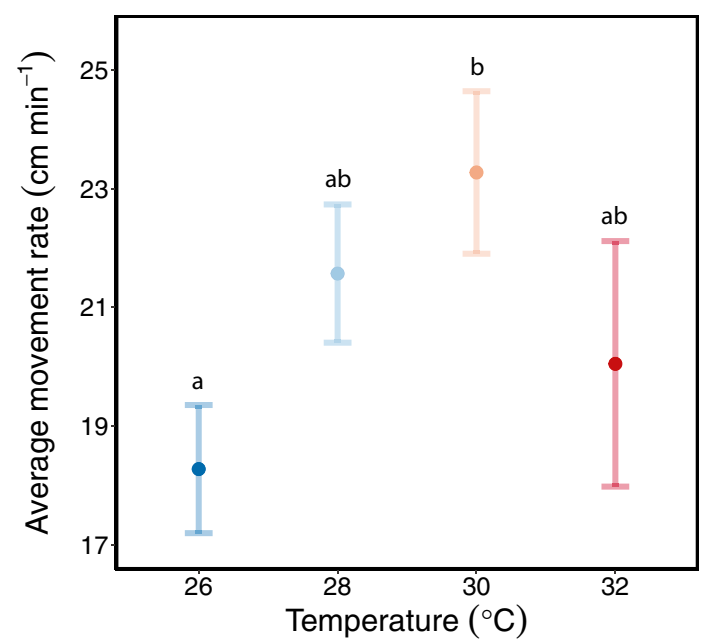

observations). Estimated marginal means are provided $( \pm S E)$. Letters represent significant differences between temperatures (Tukey method, $p<0.05$ ) 
Table 2 Output of the linear mixed effects model on the effect of temperature (T) treatment, run, and their interaction on the standard metabolic rate $\left(\mathrm{mg} \mathrm{O}_{2} \mathrm{~g}^{-1} \mathrm{~h}^{-1}\right)$ of Acanthaster cf. solaris ( $n=42 \mathrm{CoTS}, n=76$ observations).

\begin{tabular}{|c|c|c|c|c|}
\hline Response & Factor & Num $d f$, Den $d f$ & $F$ & $p$ value \\
\hline \multirow[t]{3}{*}{ Standard metabolic rate $\left(\mathrm{mg} \mathrm{O}_{2} \mathrm{~g}^{-1} \mathrm{~h}^{-1}\right)$} & Temperature treatment & 3,38 & 11.76 & $<0.001$ \\
\hline & Run & 1,30 & 0.30 & 0.587 \\
\hline & $\mathrm{T}$ Treatment $\mathrm{x}$ run & 3,30 & 0.34 & 0.798 \\
\hline
\end{tabular}

The response was log-transformed in the model to meet the normality assumption. Significant $p$ values are in bold

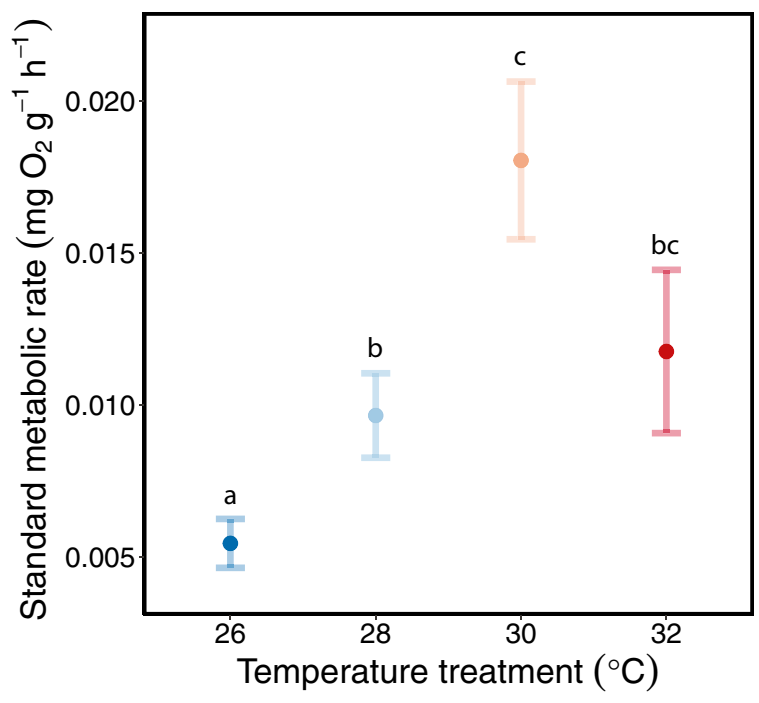

Fig. 3 The estimated marginal means $( \pm S E)$ for the effect of temperature treatment on the standard metabolic rate $\left(\mathrm{mg} \mathrm{O}_{2} \mathrm{~g}^{-1} \mathrm{~h}^{-1}\right)$ of Acanthaster cf. solaris ( $n=42$ CoTS, $n=76$ observations). Letters represent significant differences between treatments (Tukey method, $p<0.05)$

the SMR of starfish in the $32{ }^{\circ} \mathrm{C}$ treatment was $33 \%\left(\mathrm{Q}_{10}\right.$ : 0.1) lower than those in the $30^{\circ} \mathrm{C}$ treatment (Fig. 3, see S3 in Online Resource). The run did not significantly impact the SMR, and there was no interaction between temperature treatment and run (Table 2). The positive correlation between the weight of the starfish and the SMR was similar in the majority of the treatments $(b=0.96,1.02$ and 0.97 for the 26,28 and $32{ }^{\circ} \mathrm{C}$ treatments, respectively), but was lower in the $30^{\circ} \mathrm{C}$ treatment ( $b=0.70$, see $\mathrm{S} 4$ in Online Resource).

\section{Survival}

We found an overall significant effect of temperature treatment on the probability of survival (Log-rank, $\chi^{2}=25.30$, $d f=3, p<0.001)$. The difference in survival between treatment pairs was only significant for the $32{ }^{\circ} \mathrm{C}(75 \%$ mortality) treatment compared to the $26^{\circ} \mathrm{C}$ ( $p<0.001,0 \%$ mortality), $28{ }^{\circ} \mathrm{C}(p=0.008,17 \%$ mortality $)$ and $30{ }^{\circ} \mathrm{C}(p=0.012,25 \%$ mortality) treatments, respectively (Fig. 4 ). The Cox proportional hazards model further supports this result (Likelihood

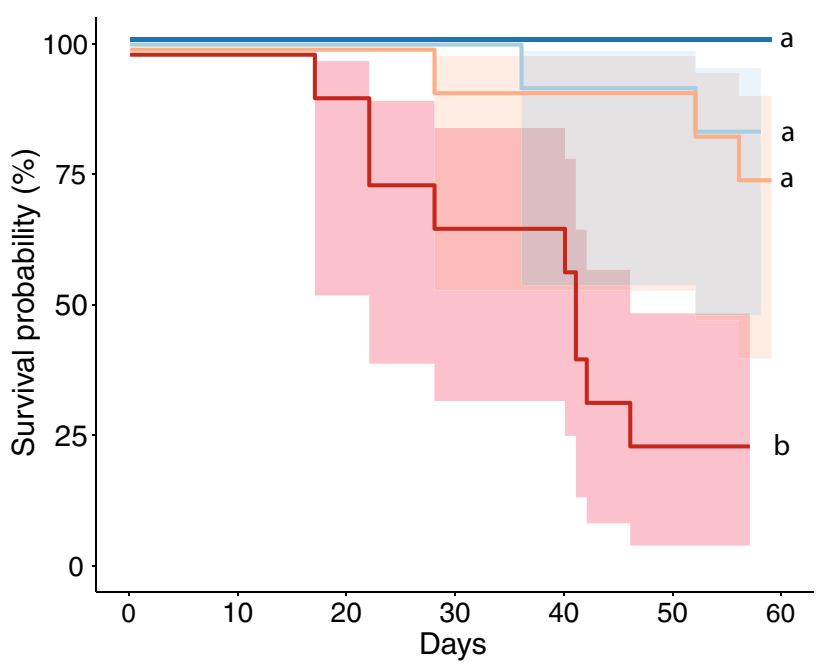

Fig. 4 Kaplan-Meier survival curve for the effect of the $26^{\circ} \mathrm{C}$ (dark blue), $28{ }^{\circ} \mathrm{C}$ (light blue), $30{ }^{\circ} \mathrm{C}$ (orange) and $32{ }^{\circ} \mathrm{C}$ (red) treatments on survival probability (\%) in Acanthaster cf. solaris $(n=48)$ over 59 days. The shaded bands represent the $95 \%$ confidence intervals. The survival curve for each temperature treatment began at $100 \%$. The overlapping lines of the four treatments were offset horizontally, in order for their complete survival curve to be visualised. Final temperatures were reached for the 28,30 and $32{ }^{\circ} \mathrm{C}$ treatments on days 5,12 , and 19 , respectively. The righting and movement experiments took place on days $1,8,15$ and 22. Letters represent significant differences between temperature treatments (Benjamini-Hochberg method, $p<0.05)$

ratio test $=11.66, d f=2, p=0.003)$, with hazard ratios revealing a sevenfold $(p=0.007)$ and fourfold $(p=0.012)$ lower probability of survival in the $32{ }^{\circ} \mathrm{C}$ compared to the $28{ }^{\circ} \mathrm{C}$ and $30^{\circ} \mathrm{C}$ treatments, respectively (Table 3 ). We observed the first mortality event on day 17 . The deceased starfish was from the highest temperature treatment when the water temperature was approximately $31{ }^{\circ} \mathrm{C}$. All remaining deaths occurred after the final temperatures were reached, with the two subsequent deaths occurring 3 days after $32^{\circ} \mathrm{C}$ was reached in the applicable temperature treatment. The first deaths in the $30^{\circ} \mathrm{C}$ and $28{ }^{\circ} \mathrm{C}$ treatments occurred on days 28 and 36, respectively, 13 and 28 days after these final temperatures were reached. We found no significant effect of starfish wet weight (g) on the probability of survival (Cox 
Table 3 Results of the Cox proportional hazards model indicating the probability of survival in Acanthaster cf. solaris $(n=48$ CoTS) between temperature treatment pairs.

\begin{tabular}{lllll}
\hline $\begin{array}{l}\text { Treatment } \\
\text { comparison }\end{array}$ & Hazard ratio & Lower 95\% CI & Upper 95\% CI & $p$ value \\
\hline $28-30{ }^{\circ} \mathrm{C}$ & 1.51 & 0.25 & 9.05 & 0.651 \\
$28-32{ }^{\circ} \mathrm{C}$ & 8.30 & 1.76 & 39.07 & $\mathbf{0 . 0 0 7}$ \\
$30-32{ }^{\circ} \mathrm{C}$ & 5.49 & 1.46 & 20.70 & $\mathbf{0 . 0 1 2}$ \\
\hline
\end{tabular}

The $26{ }^{\circ} \mathrm{C}$ control treatment could not be included due to the lack of 'events'. The hazard ratios, lower and upper $95 \%$ confidence intervals and $p$ values (significant values in bold) are provided. The hazard ratios -1 reveals the -fold difference in the probability of survival between treatments

proportional hazards model, Likelihood ratio test $=1.45$, $d f=1, p=0.228$ ).

\section{Discussion}

Establishing the thermal sensitivity of the corallivorous Pacific crown-of-thorns starfish is an essential step forward in understanding how future shifts in environmental temperature may alter the impact of this asteroid on the reef. In the present study, we found that seawater temperatures of $32{ }^{\circ} \mathrm{C}$ had negative effects on the performance and survival of CoTS. Average movement rates and SMR increased from $26{ }^{\circ} \mathrm{C}$ to $30{ }^{\circ} \mathrm{C}$, and over this thermal range survival was, for the most part, maintained. However, starfish at $32{ }^{\circ} \mathrm{C}$ had a lower SMR, reduced movement rate and a lower probability of survival, than those at $30^{\circ} \mathrm{C}$. This temperature is approximately $4{ }^{\circ} \mathrm{C}$ above the average, and $2{ }^{\circ} \mathrm{C}$ and above the maximal summer temperatures commonly experienced on the central mid-shelf of the GBR (AIMS 2021a, b), but it is predicted that temperatures of $32{ }^{\circ} \mathrm{C}$ will be frequently exceeded under near future climate change (IPCC 2013, 2021; Hoegh-Guldberg et al. 2018).

In nature it is expected that activity rates of organisms will decline when thermally stressed (Peck et al. 2008; Kidawa et al. 2010; Pörtner et al. 2017; Sun et al. 2018; Lang et al. 2021). In the present study, we observed that average movement rate increased with temperature until $30^{\circ} \mathrm{C}$, but slowed at $32{ }^{\circ} \mathrm{C}\left(14 \%\right.$ decrease compared to $\left.30{ }^{\circ} \mathrm{C}\right)$, indicating that starfish may experience thermal stress at this degree of ocean warming. In contrast, water temperature had little effect on righting time. This lack of thermal sensitivity is not uncommon (Wood et al. 2010; Zhang et al. 2017) and could be a consequence of the importance of this behaviour to avoid injury and predation, such that CoTS have evolved to invest a great deal of energy in maintaining their natural orientation (Lawrence 1984; Wood et al. 2010; Deaker et al. 2021). The differing responses between the two activities may, however, be a product of the methodological design. Because movement rate was assessed directly after righting time, the latter response may be impacted by the energy investment in the prior activity (Lawrence 1984). Whatever the exact cause of our observations, the additional costs of activity seem to be limited at $32{ }^{\circ} \mathrm{C}$, due to reduced aerobic metabolism, and therefore energy production of CoTS at this temperature. Constraints in energy production at high temperatures appears particularly relevant to larger (adult) individuals, highlighted by the lower value of $b$ for average movement rate at $32{ }^{\circ} \mathrm{C}$, compared to cooler temperatures (Lawrence 1984; Pörtner 2001; 2002; Doyle et al. 2012; Pörtner et al. 2017). It is currently unknown how the activity of CoTS will be influenced by warmer temperatures in nature. Environmental signals from predators, prey and conspecifics have a substantial impact on this asteroid, and provide a strong impetus to move away or towards such signals (Hall et al. 2017; Pratchett et al. 2017). This may result in the starfish maintaining high activity levels during marine heatwaves, potentially at the expense of other biological processes and behaviours (Lawrence 1984).

Reductions in aerobic capacity and associated energy reserves is expected to be a major contributor to compromised performance (including activity levels) in a warmer ocean (Pörtner et al. 2017; Lang et al. 2021). In this study, starfish in the $32{ }^{\circ} \mathrm{C}$ temperature treatment had a $33 \%$ slower SMR, compared to those in the $30{ }^{\circ} \mathrm{C}$ treatment, similar to the decline in movement rate observed between the same temperatures. The lower SMR in the highest temperature treatment is likely a result of the depression of aerobic metabolism, and an increased reliance on energy deficient, and unsustainable anaerobic metabolism (Pörtner 2001, 2002; Pörtner et al. 2017; Lang et al. 2021). In the present study, aerobic metabolic decline occurred at temperatures which were at least $1{ }^{\circ} \mathrm{C}$ cooler than observed in acute ramping trials $\left(24-36{ }^{\circ} \mathrm{C}\right.$ over $\left.12 \mathrm{~h}\right)$ in CoTS that were collected from the same location and at the same time of the year. Although for smaller CoTS, metabolic depression was not observed even at temperatures as high as $36^{\circ} \mathrm{C}$ when acutely exposed (Lang et al. 2021). The differing observations between these two studies is likely a result of factors that generally lead to compromised performance only after prolonged exposure to sub-optimal temperatures, such as mitochondrial failure (Pörtner 2002; Schulte et al. 2011), protein denaturation (Pörtner 2001, 2002; Pörtner et al. 2017) and oxidative damage (Pörtner 2002; Pörtner et al. 2017).

Aside from the lower SMR of CoTS at $32{ }^{\circ} \mathrm{C}$, we observed a $260 \%$ higher SMR of individuals in the $30{ }^{\circ} \mathrm{C}$ compared to the $26{ }^{\circ} \mathrm{C}$ treatment $\left(\mathrm{Q}_{10}: 24.6\right)$. This is likely a result of the inherent increased rate of chemical reactions and cellular processes at higher temperatures (Peck and Prothero-Thomas 2002; Clarke and Fraser 2004; Schulte 2015; Harianto et al. 2018). The high $Q_{10}$ coefficient indicates that CoTS have a 
very high physiological thermal sensitivity across this testing range, which is far greater than observed in temperate echinoderms $\left(\mathrm{Q}_{10}: \sim 1.0-3.0\right.$; Christensen et al. 2011; Weber et al. 2013; Harianto et al. 2018). It is not surprising that tropical species, such as CoTS may be more thermosensitive than temperate species, considering that they evolved in a stable thermal environment, and are therefore less equipped to cope with extreme temperature fluctuations (Peck et al. 2010; Nguyen et al. 2011). Such a substantial increase in SMR with temperature is concerning because this would mean that CoTS would need to consume more coral prey to meet increased energetic demands, potentially resulting in greater impacts on coral communities (Barbeau and Scheibling 1994; McBride et al. 1997; Siikavuopio et al. 2008; Kamya et al. 2018; Haywood et al. 2019; Keesing et al. 2019; Kühnhold et al. 2019). Although, a smaller $b$ in the $30{ }^{\circ} \mathrm{C}$ treatment (that has the highest mean SMR), highlights lower relative upper limits to SMR in the larger individuals, which naturally consume more coral, compared to smaller conspecifics (Lawrence 1984; Pörtner 2001; 2002; Doyle et al. 2012; Pörtner et al. 2017).

While CoTS are able to withstand temperatures exceeding $36{ }^{\circ} \mathrm{C}$ acutely (Lang et al. 2021), we observed that the ecological thermal limits of this asteroid are likely between 30 and $32{ }^{\circ} \mathrm{C}$, which appears conserved between starfish across the tested weight distribution (10-1556 g). Here, starfish in the $32{ }^{\circ} \mathrm{C}$ temperature treatment exhibited a four- and sevenfold lower probability of survival than those in the $30^{\circ} \mathrm{C}$ and $28^{\circ} \mathrm{C}$ treatments, respectively. Mortality occurred within a couple of days of the water temperature reaching $\sim 31-32{ }^{\circ} \mathrm{C}$, indicating that even brief marine heatwaves that reach these temperatures may induce mortality in CoTS. Yet, $25 \%$ of starfish were able to survive extended exposure to $32{ }^{\circ} \mathrm{C}$, suggesting that thermally tolerant individuals may persist in a warmer ocean (Binyon 1972; Johnson and Babcock 1994; Pörtner 2002). The present aquarium study may, however, overestimate survival that would occur in nature, due to a higher risk of disease at higher temperatures, either due to the greater pathogen virulence or lower host defences (Bates et al. 2009; Kohl et al. 2016; Hewson et al. 2018; Uthicke et al. 2021). Even if some CoTS are able to survive future extreme heating events, a greater amount of energy required for maintaining homeostasis may result in a lower energy investment in reproduction (Brockington and Clarke 2001; Siikavuopio et al. 2006, 2008; Uthicke et al. 2014; Delorme and Sewell 2016; Hue et al. 2020). CoTS from New Caledonia, for instance, produced significantly smaller eggs, had poorer fertilisation success and a reduced gonado-somatic index with only $2{ }^{\circ} \mathrm{C}$ warming above the ambient summertime seawater temperature (Hue et al. 2020). Furthermore, a recent cross-generational study on the sea urchin Echinometra sp. A from the GBR found that there were negative carry-over effects from parents to offspring reared in predicted near-future ocean conditions $\left(+1{ }^{\circ} \mathrm{C}, 685 \mathrm{ppm} ;+2{ }^{\circ} \mathrm{C}, 940 \mathrm{ppm}\right)$, providing uncertainty regarding the adaptive capacity of echinoderms (Uthicke et al. 2021).

In the current study, we present evidence for thermal effects on the performance and survival of CoTS. An increased performance of CoTS when exposed to current maximal summertime temperatures $\left(\sim 30^{\circ} \mathrm{C}\right)$, which may become more commonly experienced prior to the end of the century (AIMS 2021a, b; IPCC 2021; Hoegh-Guldberg et al. 2018), could result in a higher incidence and severity of population irruptions. Considering the faster metabolic rates $(260 \%)$, movement rates $(27 \%)$ and probably feeding rates of CoTS at this optimal temperature, these irruptions may result in increased coral loss on the GBR (De'ath et al. 2012; Mellin et al. 2019). Elevated coral predation will reduce the likelihood of recovery for corals already suffering from cumulative disturbance effects caused by temperature-induced bleaching and cyclones, among other stressors (De' ath et al. 2012; Vercelloni et al. 2017; Mellin et al. 2019).

While moderate increases in temperature (up to $30^{\circ} \mathrm{C}$ ) may increase the incidence and impacts of population irruptions of CoTS, the performance and survival of coral-feeding CoTS is expected to be greatly compromised at $32^{\circ} \mathrm{C}$, corresponding with projected end of century temperatures (IPCC 2013, 2021; Kamya et al. 2014; Hoegh-Guldberg et al. 2018; Lough et al. 2018; AIMS 2021a, b). However, at these temperatures, increased coral bleaching and mortality will more than offset benefits accrued from reduced incidence of population irruptions of CoTS (Eisenlord et al. 2016; van Hooidonk et al. 2016; GBRMPA 2019; Castro-Sanguino et al. 2021). Moreover, CoTS may have some capacity to acclimate or adapt to a warmer environment (Schulte et al. 2011; Schulte 2015; Pörtner et al. 2017; but see Uthicke et al. 2021). If CoTS are able to adjust their metabolism and oxygen requirements, and activity levels at supra-optimal temperatures, they may be able to conserve more energy, reducing their nutritional requirements (Pörtner et al. 2017). As a consequence, CoTS may switch their feeding preferences to feed more readily on partially bleached corals, which have lower nutritional value, but will be more common in a warmer ocean (MacArthur and Pianka 1966; Glynn 1985; Rodrigues and Grottoli 2007; Keesing et al. 2019). If unable to acclimate or adapt to warmer conditions, CoTS populations may persist by redistributing to cooler, more southerly reefs (Sill and Dawson 2021), facilitated by larval dispersal (Dight et al. 1990). However, population redistributions may be constrained by the dispersal capacity of CoTS larvae in a warmer ocean (Dight et al. 1990) and the availability of suitable settlement substrate (Britton et al. 2021). Acclimation and adaptation capacity, as well as range shifts may result in CoTS continuing to be a significant 
threat on the reef for years to come (De'ath et al. 2012; Mellin et al. 2019). For this reason, it is axiomatic that these possibilities are investigated.

Supplementary Information The online version contains supplementary material available at https://doi.org/10.1007/s00227-022-04027-w.

Acknowledgements We would like to thank the technicians at the Marine and Aquaculture Research Facility Unit, James Cook University for aiding in the set-up and maintenance of this project, and the reviewers of this manuscript. We acknowledge the Traditional Custodians of the land where this work was conducted, and pay respect to Elders past and present.

Author contributions BJL, MSP, JMD and SU designed the study. BJL, MSP, JMD and PCD carried out the experiments. BJL analysed the data and wrote the manuscript, with significant contributions from all other authors.

Funding Open Access funding enabled and organized by CAUL and its Member Institutions. This research was supported by the Australian Research Council's Centre of Excellence for Coral Reef Studies and an ARC Future Fellowship (JMD FT190100015).

Data availability Data is available in Research Data JCU from https:// doi.org/10.25903/y8zk-7483

Code availability $\mathrm{R}$ code is available in Research Data JCU from https://doi.org/10.25903/y8zk-7483

\section{Declarations}

Conflict of interest All authors declare no conflicts of interest.

Ethical approval Starfish were collected under the Great Barrier Marine Park permit G15/37535.1. Echinoderms are exempt from animal ethics approvals in Australia.

Consent to participate Consent to participate was obtained from all authors.

Consent for publication Consent for publication was obtained from all authors.

Open Access This article is licensed under a Creative Commons Attribution 4.0 International License, which permits use, sharing, adaptation, distribution and reproduction in any medium or format, as long as you give appropriate credit to the original author(s) and the source, provide a link to the Creative Commons licence, and indicate if changes were made. The images or other third party material in this article are included in the article's Creative Commons licence, unless indicated otherwise in a credit line to the material. If material is not included in the article's Creative Commons licence and your intended use is not permitted by statutory regulation or exceeds the permitted use, you will need to obtain permission directly from the copyright holder. To view a copy of this licence, visit http://creativecommons.org/licenses/by/4.0/.

\section{References}

Australian Institute of Marine Science (AIMS) (2021a) Sea water temperature logger data at Davies Reef, Great Barrer Reef From 01 January 2016 to 31 December 2020. https://data.aims.gov.au/ aimsrtds/datatool.xhtml?site $=4$. Accessed 26 January 2021a

Australian Institute of Marine Science (AIMS) (2021b) Sea water temperature logger data at Lizard Island, Great Barrer Reef From 01 January 2016 to 10 October 2020. https://data.aims.gov.au/aimsr tds/datatool.xhtml?site $=1166$. Accessed 26 January $2021 \mathrm{~b}$

Baird AH, Pratchett MS, Hoey AS, Herdiana Y, Campbell SJ (2013) Acanthaster planci is a major cause of coral mortality in Indonesia. Coral Reefs 32:803-812. https://doi.org/10.1007/ s00338-013-1025-1

Barbeau MA, Scheibling RE (1994) Temperature effects on predation of juvenile sea scallops [Placopecten magellanicus (Gmelin)] by sea stars (Asterias vulgaris Verrill) and crabs (Cancer irroratus Say). J Exp Mar Biol Ecol 182:27-47. https://doi.org/10.1016/ 0022-0981(94)90209-7

Bates AE, Hilton BJ, Harley CD (2009) Effects of temperature, season and locality on wasting disease in the keystone predatory sea star Pisaster ochraceus. Dis Aquat Organ 86:245-251. https://doi.org/ 10.3354/dao02125

Binyon J (1972) Sensory physiology. In: Kerkut GA (ed) Physiology of echinoderms. Pergamon Press, Oxford, International series of monographs in pure and applied biology, pp 80-123

Britton D, Mundy CN, Noisette F, McGraw CM, Hurd CL (2021) Crustose coralline algae display sensitivity to near future global ocean change scenarios. ICES J Mar Sci. https://doi.org/10.1093/icesj $\mathrm{ms} / \mathrm{fsab} 220$

Brockington S, Clarke A (2001) The relative influence of temperature and food on the metabolism of a marine invertebrate. J Exp Mar Biol Ecol 258:87-99. https://doi.org/10.1016/S0022-0981(00) 00347-6

Brothers CJ, McClintock JB (2015) The effects of climate-induced elevated seawater temperature on the covering behavior, righting response, and Aristotle's lantern reflex of the sea urchin Lytechinus variegatus. J Exp Mar Biol Ecol 467:33-38. https://doi.org/ 10.1016/j.jembe.2015.02.019

Bureau of meteorology (2020) 2020 marine heatwave on the great barrier reef. Australian Government, Melbourne

Byrne M, Gonzalez-Bernat M, Doo S, Foo S, Soars N, Lamare M (2013) Effects of ocean warming and acidification on embryos and non-calcifying larvae of the invasive sea star Patiriella regularis. Mar Ecol Prog Ser 473:235-246. https://doi.org/10.3354/ meps 10058

Caballes CF (2017) Environmental influences on the reproductive biology and early life history of the crown-of-thorns starfish thesis. PhD Thesis James Cook Univ. https://doi.org/10.4225/28/5afb5 be $71 \mathrm{fb} 36$

Caballes CF, Pratchett MS, Kerr AM, Rivera-Posada JA (2016) The role of maternal nutrition on oocyte size and quality, with respect to early larval development in the coral-eating starfish, Acanthaster planci. PLoS ONE 11:e0158007. https://doi.org/10.1371/ journal.pone.0158007

Caballes CF, Pratchett MS, Raymundo ML, Rivera-Posada JA (2017) Environmental tipping points for sperm motility, fertilization, and embryonic development in the crown-of-thorns starfish. Diversity 9:10. https://doi.org/10.3390/d9010010

Castro-Sanguino C, Ortiz JC, Thompson A, Wolff NH, Ferrari R, Robson B, Magno-Canto MM, Puotinen M, Fabricius KE, Uthicke S (2021) Reef state and performance as indicators of cumulative impacts on coral reefs. Ecol Indic. https://doi.org/10.1016/j.ecoli nd.2020.107335 
Chen C-P, Chen B-Y (1993) The effect of temperature-salinity combinations on survival and growth of juvenile Patiriella pseudoexigua (Echinodermata: asteroidea). Mar Biol 115:119-122. https:// doi.org/10.1007/BF00349393

Christensen AB, Nguyen HD, Byrne M (2011) Thermotolerance and the effects of hypercapnia on the metabolic rate of the ophiuroid Ophionereis schayeri: Inferences for survivorship in a changing ocean. J Exp Mar Biol Ecol 403:31-38. https://doi.org/10.1016/j. jembe.2011.04.002

Christensen AB, Radivojevich KO, Pyne MI (2017) Effects of $\mathrm{CO}_{2}, \mathrm{pH}$ and temperature on respiration and regeneration in the burrowing brittle stars Hemipholis cordifera and Microphiopholis gracillima. J Exp Mar Biol Ecol 495:13-23. https://doi.org/10.1016/j.jembe. 2017.05.012

Clark TD, Sandblom E, Jutfelt F (2013) Aerobic scope measurements of fishes in an era of climate change: respirometry, relevance and recommendations. J Exp Biol 216:2771-2782. https://doi.org/10. $1242 /$ jeb. 084251

Clarke A, Fraser KPP (2004) Why does metabolism scale with temperature? Funct Ecol 18:243-251. https://doi.org/10.1111/j.02698463.2004.00841.x

Deaker DJ, Balogh R, Dworjanyn SA, Mos B, Byrne M (2021) Echidnas of the sea: the defensive behavior of juvenile and adult crownof-thorns sea stars. Biol Bull. https://doi.org/10.1086/716777

De'ath G, Fabricius KE, Sweatman H, Puotinen M (2012) The 27-year decline of coral cover on the Great Barrier Reef and its causes. Proc Natl Acad Sci USA 109:17995-17999. https://doi.org/10. 1073/pnas. 1208909109

Delorme NJ, Sewell MA (2016) Effects of warm acclimation on physiology and gonad development in the sea urchin Evechinus chloroticus. Comp Biochem Physiol A Mol Integr Physiol 198:33-40. https://doi.org/10.1016/j.cbpa.2016.03.020

Dight IJ, James MK, Bode L (1990) Modelling the larval dispersal of Acanthaster planci II. Pattern Reef Connectivity Coral Reefs 9:125-134. https://doi.org/10.1007/BF00258224

Doyle SR, Momo FR, Brêthes JC, Ferreyra GA (2012) Metabolic rate and food availability of the Antarctic amphipod Gondogeneia antarctica (Chevreux 1906): seasonal variation in allometric scaling and temperature dependence. Polar Biol 35:413-424. https://doi. org/10.1007/s00300-011-1089-8

Eisenlord ME, Groner ML, Yoshioka RM, Elliott J, Maynard J, Fradkin S, Turner M, Pyne K, Rivlin N, van Hooidonk R, Harvell CD (2016) Ochre star mortality during the 2014 wasting disease epizootic: role of population size structure and temperature. Philos Trans R Soc Lond B Biol Sci 371:20150212. https://doi.org/10. 1098/rstb.2015.0212

Fang J, Zhang J, Jiang Z, Zhao X, Jiang X, Du M, Yaping G, Fang $\mathrm{J}$ (2015a) Tolerance, oxygen consumption and ammonia excretion of Ophiopholis sarsii vadicola in different temperatures and salinities. J Ocean Univ China 14:549-556. https://doi.org/10. 1007/s11802-015-2513-4

Fang J, Zhang J, Liu Y, Jiang Z, Mao Y, Fang J (2015b) Effects of temperature and salinity on mortality and metabolism of $O p h i$ opholis mirabilis. Mar Biol Res 11:157-167. https://doi.org/10. 1080/17451000.2014.904884

Glynn PW (1985) Corallivore population sizes and feeding effects following El Nino (1982-1983) associated coral mortality in Panama. Proc Fifth Int Coral Reef Congress, Tahiti 4:183-188

Great barrier reef marine park authority (GBRMPA) (2019) Great barrier reef outlook report 2019. GBRMPA, Townsville

Hall MR, Kocot KM, Baughman KW, Fernandez-Valverde SL, Gauthier MEA, Hatleberg WL, Krishnan A, McDougall C, Motti CA, Shoguchi E, Wang T, Xiang X, Zhao M, Bose U, Shinzato C, Hisata K, Fujie M, Kanda M, Cummins SF, Satoh N, Degnan SM, Degnan BM (2017) The crown-of-thorns starfish genome as a guide for biocontrol of this coral reef pest. Nature 544:231-234. https://doi.org/10.1038/nature22033

Harianto J, Nguyen HD, Holmes SP, Byrne M (2018) The effect of warming on mortality, metabolic rate, heat-shock protein response and gonad growth in thermally acclimated sea urchins (Heliocidaris erythrogramma). Mar Biol 165:96. https://doi.org/10.1007/ s00227-018-3353-8

Haywood MDE, Thomson DP, Babcock RC, Pillans RD, Keesing JK, Miller M, Rochester WA, Donovan A, Evans RD, Shedrawi G, Field SN (2019) Crown-of-thorns starfish impede the recovery potential of coral reefs following bleaching. Mar Biol 166:99. https://doi.org/10.1007/s00227-019-3543-z

Hewson I, Bistolas KSI, Quijano Cardé EM, Button JB, Foster PJ, Flanzenbaum JM, Kocian J, Lewis CK (2018) Investigating the complex association between viral ecology, environment, and Northeast pacific sea star wasting. Front Mar Sci. https://doi.org/ 10.3389/fmars.2018.00077

Hobday AJ, Alexander LV, Perkins SE, Smale DA, Straub SC, Oliver ECJ, Benthuysen JA, Burrows MT, Donat MG, Feng M, Holbrook NJ, Moore PJ, Scannell HA, Sen Gupta A, Wernberg T (2016) A hierarchical approach to defining marine heatwaves. Prog Oceanogr 141:227-238. https://doi.org/10.1016/j.pocean.2015.12.014

Hoegh-Guldberg O, Jacob D, Taylor M, Bindi M, Brown S, Camilloni I, Diedhiou A, Djalante R, Ebi KL, Engelbrecht F, Guiot J, Hijioka Y, Mehrotra S, Payne A, Seneviratne SI, Thomas A, Warren R, Zhou G. (2018) Impacts of $1.5^{\circ} \mathrm{C}$ of global warming on natural and human systems. In: Masson-Delmotte V, Zhai P, Pörtner H-O, Roberts D, Skea J, Shukl PR, Pirani A, MoufoumaOkia W, Péan C, Pidcock R, Connors S, Matthews JBR, Chen Y, Zhou X, Gomis MI, Lonnoy, E, Maycock T, Tignor M, Waterfield $\mathrm{T}$ (eds) Global warming of an IPCC special report on the impacts of global warming of $1.5^{\circ} \mathrm{C}$ above pre-industrial levels and related global greenhouse gas emission pathways, in the context of strengthening the global response to the threat of climate change, sustainable development, and efforts to eradicate poverty. IPCC, Geneva, pp 175-311

Hue T, Chateau O, Lecellier G, Kayal M, Lanos N, Gossuin H, Adjeroud M, Dumas P (2020) Temperature affects the reproductive outputs of coral-eating starfish Acanthaster spp after adult exposure to near-future ocean warming and acidification. Mar Env Res. https://doi.org/10.1016/j.marenvres.2020.105164

Illing B, Downie AT, Beghin M, Rummer JL (2020) Critical thermal maxima of early life stages of three tropical fishes: effects of rearing temperature and experimental heating rate. J Therm Biol. https://doi.org/10.1016/j.jtherbio.2020.102582

IPCC (2013) Summary for policymakers. In: Stocker TF, Qin D, Plattner G-K, Tignor M, Allen SK, Boschung J, Nauels A, Xia Y, Bex V, Midgley PM (eds) Climate change 2013: the physical science basis contribution of working group to the fifth assessment report of the intergovernmental panel on climate change. Cambridge University Press, Cambridge

IPCC (2021) Summary for policymakers. In: Masson-Delmotte V, Zhai P, Pirani A, Connors SL, Péan C, Berger S, Caud N, Chen Y, Goldfarb L, Gomis MI, Huang M, Leitzell K, Lonnoy E, Matthews JBR, Maycock TK, Waterfield T, Yelekçi O, Yu R, Zhou B (eds) Climate change 2021: the physical science basis contribution of working group I to the sixth assessment report of the intergovernmental panel on climate change. Cambridge University Press, In Press

Johnson LG, Babcock RC (1994) Temperature and the larval ecology of the crown-of-thorns starfish, Acanthaster planci. Biol Bull 187:304-308. https://doi.org/10.2307/1542287

Kamya PZ, Dworjanyn SA, Hardy N, Mos B, Uthicke S, Byrne M (2014) Larvae of the coral eating crown-of-thorns starfish, 
Acanthaster planci in a warmer-high $\mathrm{CO}_{2}$ ocean. Glob Change Biol 20:3365-3376. https://doi.org/10.1111/gcb.12530

Kamya PZ, Byrne M, Graba-Landry A, Dworjanyn SA (2016) Nearfuture ocean acidification enhances the feeding rate and development of the herbivorous juveniles of the crown-of-thorns starfish, Acanthaster planci. Coral Reefs 35:1241-1251. https://doi.org/10. 1007/s00338-016-1480-6

Kamya PZ, Byrne M, Mos B, Dworjanyn SA (2018) Enhanced performance of juvenile crown of thorns starfish in a warmhigh $\mathrm{CO}_{2}$ ocean exacerbates poor growth and survival of their coral prey. Coral Reefs 37:751-762. https://doi.org/10.1007/ s00338-018-1699-5

Kashenko SD (2006) The combined effect of temperature and salinity on development of the sea star Asterina pectinifera. Russ J Mar Biol 32:37-44. https://doi.org/10.1134/s1063074006010056

Keesing JK, Thomson DP, Haywood MDE, Babcock RC (2019) Two time losers: selective feeding by crown-of-thorns starfish on corals most affected by successive coral-bleaching episodes on western Australian coral reefs. Mar Biol 166:72. https://doi.org/10.1007/ s00227-019-3515-3

Kidawa A, Potocka M, Janecki T (2010) The effects of temperature on the behaviour of the Antarctic sea star Odontaster validus. Pol Polar Res 31:273-284

Kleitman N (1941) The effect of temperature on the righting of echinoderms. Biol Bull 80:292-298. https://doi.org/10.2307/1537716

Kohl WT, McClure TI, Miner BG (2016) Decreased temperature facilitates short-term sea star wasting disease survival in the keystone intertidal sea star Pisaster ochraceus. PLoS ONE. https://doi.org/ 10.1371/journal.pone. 0153670

Kühnhold H, Steinmann N, Huang Y-H, Indriana L, Meyer A, Kunzmann A (2019) Temperature-induced aerobic scope and Hsp70 expression in the sea cucumber Holothuria scabra. PLoS ONE. https://doi.org/10.1371/journal.pone.0214373

Lamare M, Pecorino D, Hardy N, Liddy M, Byrne M, Uthicke S (2014) The thermal tolerance of crown-of-thorns (Acanthaster planci) embryos and bipinnaria larvae: implications for spatial and temporal variation in adult populations. Coral Reefs 33:207-219. https:// doi.org/10.1007/s00338-013-1112-3

Lang BJ, Donelson JM, Caballes CF, Doll PC, Pratchett MS (2021) Metabolic responses of pacific crown-of-thorns sea stars (Acanthaster sp) to acute warming. Biol Bull 241. https://doi.org/10. 1086/717049

Lawrence JM (1984) The energetic echinoderm. In: Keegan BF, Brendan DS (eds) Echinodermata A. A. Balkema, Rotterdam, pp 47-67

Ling SD (2013) Pushing boundaries of range and resilience: A review of range-extension by a barrens-forming sea urchin. Fernández-Palacios JM, Nascimentro L, Hernández, JC, Clemente S, González A, Díaz-González. JP Servicio de publicaciones Santa Cruz de Tenerife, Universidad de La Laguna, pp 413-442

Lough JM, Anderson KD, Hughes TP (2018) Increasing thermal stress for tropical coral reefs: 1871-2017. Sci Rep 8:6079. https://doi. org/10.1038/s41598-018-24530-9

MacArthur RH, Pianka ER (1966) On optimal use of a patchy environment. Am Nat 100:603-609. https://doi.org/10.1086/282454

McBride SC, Pinnix WD, Lawrence WD, Lawrence JM, Lawrence AL, Mulligan TM (1997) The effect of temperature on the production of gonads by the sea urchin Strongylocentrotus franciscanus fed natural and prepared diets. J World Aquac Soc 28:357-365. https://doi.org/10.1111/j.1749-7345.1997.tb00282.x

Mellin C, Matthews S, Anthony KRN, Brown SC, Caley MJ, Johns KA, Osborne K, Puotinen M, Thompson A, Wolff NH, Fordham DA, MacNeil MA (2019) Spatial resilience of the great barrier reef under cumulative disturbance impacts. Glob Chang Biol 25:2431-2445. https://doi.org/10.1111/gcb.14625
Minuti JJ, Byrne M, Hemraj DA, Russell BD (2021) Capacity of an ecologically key urchin to recover from extreme events: physiological impacts of heatwaves and the road to recovery. Sci Total Env 785:147281. https://doi.org/10.1016/j.scitotenv.2021.147281

Moran PJ (1988) Crown-of-thorns starfish questions and answers. The Australian institute of marine science, Townsville

Negri AP, Smith RA, King O, Frangos J, Warne MSJ, Uthicke S (2020) Adjusting tropical marine water quality guideline values for elevated ocean temperatures. Env Sci Technol 54:1102-1110. https:// doi.org/10.1021/acs.est.9b05961

Nguyen KD, Morley SA, Lai CH, Clark MS, Tan KS, Bates AE, Peck LS (2011) Upper temperature limits of tropical marine ectotherms: global warming implications. PLoS ONE. https://doi. org/10.1371/journal.pone.0029340

Peck LS, Prothero-Thomas E (2002) Temperature effects on the metabolism of larvae of the Antarctic starfish Odontaster validus, using a novel micro-respirometry method. Mar Biol 141:271-276. https://doi.org/10.1007/s00227-002-0834-5

Peck LS, Webb KE, Miller A, Clark MS, Hill T (2008) Temperature limits to activity, feeding and metabolism in the Antarctic starfish Odontaster validus. Mar Ecol Prog Ser 358:181-189. https://doi. org/10.3354/meps07336

Peck LS, Clark MS, Morley SA, Massey A, Rossetti H (2009) Animal temperature limits and ecological relevance: effects of size, activity and rates of change. Funct Ecol 23:248-256. https://doi.org/ 10.1111/j.1365-2435.2008.01537.x

Peck LS, Morley SA, Clark MS (2010) Poor acclimation capacities in Antarctic marine ectotherms. Mar Biol 157:2051-2059. https:// doi.org/10.1007/s00227-010-1473-x

Pörtner H-O (2001) Climate change and temperature-dependent biogeography: oxygen limitation of thermal tolerance in animals. Naturwissenschaften 88:137-146. https://doi.org/10.1007/s0011 40100216

Pörtner H-O (2002) Climate variations and physiological basis of temperature dependent biogeography: systematic to molecular hierarchy of thermal tolerance in animals. Comp Biochem Physiol, A 132:739-761. https://doi.org/10.1016/S1095-6433(02)00045-4

Pörtner H-O, Knust R (2007) Climate change affects marine fishes through the oxygen limitation of thermal tolerance. Science 315:95-97. https://doi.org/10.1126/science.1135471

Pörtner H-O, Bock C, Mark FC (2017) Oxygen-and capacity-limited thermal tolerance: bridging ecology and physiology. J Ex Biol 220:2685-2696. https://doi.org/10.1242/jeb.134585

Pratchett MS, Caballes CF, Rivera-Posada JA, Sweatman HPA (2014) Limits to understanding and managing outbreaks of crown-ofthorns starfish (Acanthaster spp). Oceanogr Mar Biol 52:133-200. https://doi.org/10.1201/b17143-4

Pratchett MS, Cowan Z-L, Nadler LE, Caballes CF, Hoey AS, Messmer V, Fletcher CS, Westcott DA, Ling SD (2017) Body size and substrate type modulate movement by the western Pacific crownof-thorns starfish, Acanthaster solaris. PLoS ONE. https://doi.org/ 10.1371/journal.pone.0180805

Pratchett MS, Nadler LE, Burn D, Lang BJ, Messmer V, Caballes CF (2021) Reproductive investment and fecundity of pacific crownof-thorns starfish (Acanthaster cf solaris) on the great barrier reef. Mar Biol. https://doi.org/10.1007/s00227-021-03897-w

Prosser CL (1991) Comparative animal physiology, environmental and metabolic animal physiology, part a. Wiley-Liss, New York

Rahman S, Tsuchiya M, Uehara T (2009) Effects of temperature on hatching rate, embryonic development and early larval survival of the edible sea urchin Tripneustes gratilla. Biologia. https://doi. org/10.2478/s11756-009-0135-2

Reese ES (1966) Chapter 8 The complex behaviour of echinoderms. In: Boolootian RA (ed) Physiology of echinodermata. Interscience publishers, New York, pp 157-218 
Rodrigues LJ, Grottoli AG (2007) Energy reserves and metabolism as indicators of coral recovery from bleaching. Limnol Oceanogr 52:1874-1882. https://doi.org/10.4319/lo.2007.52.5.1874

RStudioTeam (2016) RStudio: Integrated development for R, Boston, Massachusetts http://www.rstudio.com/. Accessed 23rd August 2021

Rupp JH (1973) Effect of temperature on fertilization and early cleavage of some tropical echinoderms, with emphasis on Echinometra mathaei. Mar Biol 23:183-189

Schulte PM (2015) The effects of temperature on aerobic metabolism: towards a mechanistic understanding of the responses of ectotherms to a changing environment. J Exp Biol 218:1856-1866. https://doi.org/10.1242/jeb.118851

Schulte PM, Healy TM, Fangue NA (2011) Thermal performance curves, phenotypic plasticity, and the time scales of temperature exposure. Integr Comp Biol 51:691-702. https://doi.org/10.1093/ $\mathrm{icb} / \mathrm{icr} 097$

Siikavuopio SI, Christiansen JS, Dale T (2006) Effects of temperature and season on gonad growth and feed intake in the green sea urchin (Strongylocentrotus droebachiensis). Aquaculture 255:389-394. https://doi.org/10.1016/j.aquaculture.2005.12.021

Siikavuopio SI, Mortensen A, Christiansen JS (2008) Effects of body weight and temperature on feed intake, gonad growth and oxygen consumption in green sea urchin, Strongylocentrotus droebachiensis. Aquaculture 281:77-82. https://doi.org/10.1016/j.aquaculture. 2008.05.033

Sill SR, Dawson TP (2021) Climate change impacts on the ecological dynamics of two coral reef species, the humphead wrasse (Cheilinus undulatus) and crown-of-thorns starfish (Ancanthaster planci). Ecol Inform 65:101399. https://doi.org/10.1016/j.ecoinf. 2021.101399

Sparks KM, Foo SA, Uthicke S, Byrne M, Lamare M (2017) Paternal identity influences response of Acanthaster planci embryos to ocean acidification and warming. Coral Reefs 36:325-338. https:// doi.org/10.1007/s00338-016-1505-1

Stuart-Smith RD, Edgar GJ, Barrett NS, Kininmonth SJ, Bates AE (2015) Thermal biases and vulnerability to warming in the world's marine fauna. Nature 528:88-92. https://doi.org/10.1038/natur e16144

Sun J, Zhang L, Pan Y, Lin C, Wang F, Yang H (2018) Effect of water temperature on diel feeding, locomotion behaviour and digestive physiology in the sea cucumber Apostichopus japonicus. J Exp Biol. https://doi.org/10.1242/jeb.177451

Svendsen MBS, Bushnell PG, Steffensen JF (2016) Design and setup of intermittent-flow respirometry system for aquatic organisms. J Fish Biol 88:26-50. https://doi.org/10.1111/jfb.12797

Uthicke S, Liddy M, Nguyen HD, Byrne M (2014) Interactive effects of near-future temperature increase and ocean acidification on physiology and gonad development in adult Pacific sea urchin, Echinometra Sp A. Coral Reefs 33:831-845. https://doi.org/10. 1007/s00338-014-1165-y

Uthicke S, Logan M, Liddy M, Francis D, Hardy N, Lamare M (2015) Climate change as an unexpected co-factor promoting coral eating seastar (Acanthaster planci) outbreaks. Sci Rep. https://doi.org/ 10.1038/srep08402

Uthicke S, Watson S-A, Lamare M (2021) Cross-generational response of a tropical sea urchin to global change and a selection event in a 43-month mesocosm study. Glob Change Biol. https://doi.org/ 10.1111/GCB. 15657

van Hooidonk R, Maynard J, Tamelander J, Gove J, Ahmadia G, Raymundo L, Williams G, Heron SF, Planes S (2016) Local-scale projections of coral reef futures and implications of the Paris agreement. Sci Rep. https://doi.org/10.1038/srep39666

Vercelloni J, Caley MJ, Mengersen K (2017) Crown-of-thorns starfish undermine the resilience of coral populations on the great barrier reef. Glob Ecol Biogeogr 26:846-853. https://doi.org/10.1111/ geb. 12590

Weber AA, Dupont S, Chenuil A (2013) Thermotolerance and regeneration in the brittle star species complex Ophioderma longicauda: a preliminary study comparing lineages and mediterranean basins. CR Biol 336:572-581. https://doi.org/10.1016/j.crvi.2013.10.004

Wood HL, Spicer JI, Lowe DM, Widdicombe S (2010) Interaction of ocean acidification and temperature; the high cost of survival in the brittlestar Ophiura ophiura. Mar Biol 157:2001-2013. https:// doi.org/10.1007/s00227-010-1469-6

Zhang L, Zhang L, Shi D, Wei D, Chang Y, Zhao C (2017) Effects of long-term elevated temperature on covering, sheltering and righting behaviors of the sea urchin Strongylocentrotus intermedius. PeerJ 5:e3122. https://doi.org/10.7717/peerj.3122

Publisher's Note Springer Nature remains neutral with regard to jurisdictional claims in published maps and institutional affiliations. 